\title{
Discussion on the Current Situation and Development of Power Enterprise Management under the New Normal
}

\author{
Li Qichang, Song Qiang, Li Guangxiao, Wang Lin \\ State Grid Jining Power Supply Company, Jining Shandong, China, 272000,
}

Keywords: new normal, power enterprise, operation management

Abstract: There are still many problems in power companies in China at present, which lead to shortcomings such as weak market awareness and low service quality of power companies. With the continuous progress and development of the society, the current development model of power companies can no longer meet the needs of social development. The business management and management model requires further reform and innovation. Under the new normal, the premise of ensuring the stable development of electric power enterprises is to do a good job in the innovation work of electric power enterprises, including applying new technical means in the development process of enterprises, innovating innovative ideas and management strategies of enterprises, strengthening human resource management, and other related countermeasures.

The development of power companies is different from the development of other industries. Power has a wide range of uses, convenience, and efficiency. Power energy is one of the important energy industries in China. People's production and life are inseparable from power and energy. Important factors of social development and economic progress, even if sudden power outages will have certain impacts, such as: traffic chaos, enterprise suspension, etc.; such a situation will not only cause urban traffic, but also bring huge economic losses to enterprises, etc. From this, it can be seen that the influence of electric energy on society and people's lives is great. At this stage, power companies have become the main industry to improve the national economic level. With the continuous development and progress of the social economy, the development of China's power companies has also undergone great changes, and there are certain developments in the development and management of power companies. Power companies have also turned from the seller's market to the buyer's market. Under such a development background, China's power companies have gradually become market-oriented, and the development of power companies has become the focus of society.

\section{The Development Status of Power Companies}

\subsection{Lack of Market Awareness}

The production content of power companies is mainly electric energy. At present, China's power generation forms are more diversified. In addition to traditional water conservancy and wind power generation methods, there are nuclear power and solar power generation forms. Firepower and hydropower generation methods are relatively mature power generation technologies in China. The 
advantages of hydropower generation are relatively large, so it has received a lot of investment and policy support from the state, such as: no pollution, no pollution, etc. The famous Three Gorges Hydropower Station is a typical hydropower station. At this stage, the most indispensable part of people's production and life is the power resources. The power resources show the development civilization of the country to a certain extent. The traditional marketing model of China's power companies has always been in a monopoly position. Although many reforms and innovations have been carried out, there are still many problems, such as: the marketing model and management model are relatively backward, the enterprise development lacks innovation, and the standard is lacking. Management system, etc., although the company's continuous reform has achieved certain achievements, but in the actual development process, it is necessary to carry out innovation and development in line with social needs, which shows that China's electricity market has not achieved real establishment.

\subsection{The Service Quality of Power Companies is Low}

The most basic problem of China's power companies is that it is more difficult to pay fees. In many places, there are fewer windows and service points for power payment. In the service process of power companies, if there are new services such as new installations, it is more complicated to handle the relevant procedures. It is easy to bring unnecessary trouble to customers. In the peak period of electricity consumption, people have higher electricity consumption rates, and the higher the rate of power failure, the demand for electric power repairs has also increased. If there is a bad weather, the repair problem is also Will become more difficult.

\subsection{The Marketing Management Structure is Relatively Backward}

At this stage, the marketing service system of China's power companies is still relatively backward, there is no perfect marketing management structure, the relevant management system and supervision system are not relatively sound, and the functions of power enterprise services are not fully utilized. In addition, the management structure of power companies has not been adjusted in a timely manner. The marketing organization cannot change with the development needs of the society. It only realizes a single marketing function, and has not changed to market development, enterprise business decisions, etc. On the level. Moreover, due to the complexity of the marketing process of power companies, the handling of business needs to go through several relevant departments, and the approval procedures for internal work are relatively slow, which affects the efficiency of power marketing.

\section{The Problems in the Marketing Management of Power Companies}

\subsection{Enterprise Property Rights Issues}

In the property rights system of China's power companies, corporate assets are owed by the state and enterprises are also state-owned enterprises. However, the actual investment sources of enterprises are diverse. There are not only national capital investment and local capital investment, but also exist. The self-raised funds of enterprises, the related property rights issues and relationships of power companies are relatively complex, and the interests of investors and other factors, local and enterprises pay more attention to their own interests and returns, resulting in the loss of state capital investment is more serious, Relevant governments have also neglected the supervision and restraint of power companies ${ }^{[1]}$. How far can the development of power companies go, depending on the ability and level of operators and managers. If there is a lack of democratic decision-making in the 
business process of enterprises, and lack of supervision of business operations, it will lead to people with a heart to the enterprise. Control and the overhead of rights. From another point of view, the government will propose not to strengthen the control and management of enterprises from the decision-making, management, management and other aspects of power companies, and even to a certain extent, the management policy of enterprise management, the management rights of power companies Unity with the rights used, such long-term development will not only damage the rights and interests of investors but also seriously weaken the entrepreneurial spirit and enthusiasm of production and management. The traditional business philosophy makes the company feel that it is better to rely on the trees to complete the government. The requirements and objectives are basic principles that hinder the development of power companies and the ability to respond to the market, and have an adverse impact on the stable development of power companies.

\subsection{Uncoordinated Human Resource Management}

\subsubsection{Lack of rational allocation of human resources}

Human resources are the key point of power enterprise marketing. At present, the main problem in the development of power companies is the lack of professionals. In the production technology, power marketing and other positions, there has been a serious lack of professionals. As a result, the work pressure of the on-the-job employees is very high, and many employees even appear to have multiple jobs. In recent years, the growth rate of employees in power companies has been relatively low. In many cases, there will be an increase in the supply and demand of electricity, and the number of employees will be reduced. At present, the shortage of personnel in power companies has become an important issue for enterprise development. State-owned enterprises will use the traditional human resource management concept to impose a certain degree of restraint and restriction on the development of power companies. The main form of performance is the allocation of personnel only to complete the production targets. Such a situation will seriously hinder the electricity demand in the market, the quality of work, and efficiency of the company.

\subsubsection{The Lack of High-Quality Talent}

With the continuous development of the social economy, the state's investment and support for the power industry has also increased continuously. The introduction of talents for power companies through various channels not only supplements the highly educated staff, but also improves the work of power companies. Cultural water and technical experience of personnel. However, there is still a certain gap in the development needs of following the society. The proportion of high-quality professionals in power companies is still relatively low. The imbalance between the growth rate of talents and the development speed of power companies has become a real problem of social development. The lack of reserve talents in the development of power companies will directly affect the innovation of business management models and the stable and rapid development of enterprises ${ }^{[2]}$.

\subsubsection{Lack of a Sound Human Resources Management System}

Due to the influence of external factors such as state-owned enterprises, China's power companies are relatively late to start and change. The imperfect human resources management of power companies is also an indisputable fact in the development process of enterprises. Of course, there are still many human resources management. Traditional concept. The management of human resources requires the overall system of the enterprise and the effective cooperation of various departments. In the basic enterprise construction system, all departments and related systems are organically 
combined, and scientific and reasonable practice is carried out in the operation process of the enterprise. Generally speaking, in the management process of human resources of power companies, there are problems such as low level of informatization and low innovation ability. Only by solving these problems in a targeted manner, and combining the development of the national economy and related policies, follow the times. The development of the human resources management mechanism, in order to effectively improve the power resource management system.

\subsubsection{Single Business Management Model}

Power companies are a special industry different from other industries. In recent years, power companies have been in a monopoly state and have long-term economic benefits. The development of power companies does not require too much attention to the environmental changes in the market, only the supply of electricity is required. However, due to the influence of state-owned enterprises, there is no power to dispose of and control the assets of the enterprise itself, and it is impossible to carry out other types of profit-making business activities. Such a situation will also hinder the diversified development of enterprises and reduce the rationality utilization rate of enterprise resources $^{[3]}$.

\section{The Management Measures for the Development of Power Companies}

\subsection{Innovating Ideas and Technologies}

In the context of the new economic normal, power companies need to take advantage of technological innovation, seize opportunities, and create new situations. Power companies should actively contribute to the innovation of the business management model and provide relevant technical support. The fundamental condition for enterprises to go to the village and develop is technological innovation and reform. Once the technology is backward, it will be eliminated by the development of the social market. The power enterprise needs to establish an incentive system that meets the actual needs of the enterprise, and improve the internal management system. The innovation plays a certain role in promoting the adjustment of the corporate structure.

\subsection{Improve the Operation and Management Mechanism of the Enterprise}

Electric power enterprises should carry out the formulation and improvement of the management system in line with the actual situation according to the introduction of the national administrative management policy, rationally allocate human resources, and improve the efficiency of enterprise management and development. For employees on the job, the company can carry out appropriate incentives, which not only has an important impact on mobilizing the enthusiasm of employees, but also mobilize staff to explore potential business opportunities in the process of power enterprise reform, to achieve real brainstorming and further accelerate the establishment and standardization of the power enterprise management system.

\subsection{Strengthening the Concept of Business Management}

Now, we are in a new era of informationization. Information technology has occupied our lives. In modern life, there are also a large number of e-commerce platforms, which not only provide convenience for people's lives, but also bring them to major enterprises. Development opportunities. In the context of the new normal, power companies need to make full use of information technology, innovate the management philosophy of enterprises, and modernize the management concepts of enterprises according to the development form of society. Power resources are not only the resources 
used by the public, but also have the attributes of goods to serve the society. Therefore, power companies need to meet the needs of social business development ${ }^{[4]}$. Power companies need to do long-term development planning, reserve professional and technical personnel, make full use of information resources, and promote the modernization of power companies. It is more convenient for enterprises to improve their service quality and awareness.

\subsection{Strategic Management of Innovative Enterprises}

The development trend of social economy and its actual ability determine the development strategy of electric power enterprises. In order to develop long-term enterprises, it is necessary to comprehensively improve the market competitiveness of enterprises, and consider the stable and rapid development of enterprises. The work objectives are rationally planned. Compared with other industries, the operation and management of power companies is short-board, and there are no successful experiences and lessons for reference. To strengthen the management strategy of power companies, we must first carry out in-depth investigation and exploration, and increase the emphasis on the construction of related systems. Second, we must establish a scientific and rational management system and development decisions. Finally, power companies need to have comprehensive development ideas and goals. In addition, there are strict controls on market changes, effective response measures, and overall promotion of the stable development of power companies.

\subsection{Management and Optimization of Human Resources in Enterprises}

At this stage, China's social economy is constantly developing, and power companies are constantly deepening reforms. The needs of power companies for high-quality and comprehensive talents are constantly increasing, and they are more eager for technical and knowledge-based talents. This requires power companies to introduce a large number of talents from various sources and channels, and rationally allocate human resources management. Power companies should require internal staff to help and learn from each other. While conducting power resource optimization, power companies must also improve the human resources management system, fully implement the internal performance management model, and effectively manage the staff's reward and punishment system, work plan and completion according to the actual situation of the enterprise. In addition, power companies must increase the professional training of staff, conduct demonstrations of professional and technical operations, further improve the work ability and work efficiency of staff, effectively cultivate the comprehensive ability of staff, for power companies, and lay the foundation for stable development and promotion.

\section{Conclusion}

The operation and management mode of electric power enterprises has a direct impact on the development of enterprises. At present, the management level of China's electric power enterprises is still relatively low, and there are still certain problems and defects in the work process. In order to improve the management and management level of enterprises, electric power is promoted. In addition to the targeted solutions to the above problems, the stable development of enterprises should also establish countermeasures in line with the actual situation of enterprises, and better meet the development needs of power companies through the reform and innovation of business management models. 


\section{References}

[1] Ying Li. Research on the Current Situation and Improvement Measures of Power Enterprise Management under the New Normal State [J]. Science and Technology Vision, 2017 (30): 155-156.

[2] Xiaoping Fan. On How Current Power Companies Should Improve Their Management Level [J]. China Strategic Emerging Industries, 2017 (32): 173+175.

[3] Dejun Du. Analysis of Management Measures and Countermeasures for Electric Power Enterprises [J]. Low Carbon World, 2017 (19): 136-137.

[4] Xiaoxiang Guo. On the Status Quo and Measures of Power Enterprise Management under the New Normal State [J]. Commercial Economy, 2016 (03): 41-42. 